\title{
EMPLOYEE SATISFACTION ON LABOUR WELFARE MEASURES: AN EMPIRICAL EXAMINATION OF MANUFACTURING COMPANIES
}

\author{
Sanuja Shree P.N \\ $\mathrm{PhD}$ Research Scholar, Department of Commerce, \\ University of Madras, Chennai, India \\ Dr. S. Gurusamy \\ Professor \& Head, Department of Commerce, \\ University of Madras, Chennai, India \\ P. Balaji \\ Assistant Professor, Department of Commerce, \\ Guru Nanak College (Autonomous), Chennai, India
}

\begin{abstract}
This empirical research study was conducted to explore the employee satisfaction on labour welfare measures in selected manufacturing companies of Chennai city of Tamil Nadu. Exploratory and descriptive research design was adopted to collect employee's perception through a structured questionnaire with two sections by adopting non-random convenient sampling technique. The data collected were subjected to analysis using PSPP Version 1.0.1. GUI the empirical tools such as, percentage analysis, factor analysis, Independent Samples t test, Analysis of Variance (ANOVA) and weighted average mean score were used in this study to draw meaningful answer to the research questions of the study. The result indicates that, Employee Satisfaction of Welfare Measures variables have been reduced to three independent factors and the most dominant factor is Amenities Satisfaction Factor (ASF) followed by Environment Satisfaction Factor (ESF) and Monetary Satisfaction Factor (MSF) in their order of dominance. The researchers concluded that, Employees are giving importance to Welfare measures, Health measures and Safety measures in their order importance to enhance the employee satisfaction.
\end{abstract}

Key words: Welfare Measures, Manufacturing Industry, Amenities Satisfaction, Environment Satisfaction and Monetary Satisfaction. 
Cite this Article: Sanuja Shree P.N, Dr. S. Gurusamy and P. Balaji, Employee Satisfaction on Labour Welfare Measures: An Empirical Examination of Manufacturing Companies, International Journal of Production Technology and Management (IJPTM), 10(1), 2019, pp. 77-86.

http://iaeme.com/Home/issue/IJPTM?Volume=10\&Issue=1

\section{INTRODUCTION}

In recent years, labour welfare measures satisfaction has emerged as vital aspect to determine the social right of the employees. Labour welfare measures are very imperative component to maintain the cordial healthy relationship between management and employees and also to increase the standard of living of the people (Rhodes, 1998). Labour welfare measures are commonly classified into statutory and non-statutory in nature and it various based on the industry or sector for the better maintenance of employee satisfaction. The Government plays a very important role to determine the welfare measures satisfaction of employees for their socio-economic enhancement (Salamon, 1987 \& Tirole, 1994). However, these welfare measures are only to widen the area of its applicability (Briggs, $1961 \&$ Rhodes, 1998). Labour welfare is a concept of flexibility and changeability due to the nature of industry and its structure (Mishra \& Manju, 2007). Application of these labour welfare measures are primarily depends on the nature of industry, geographical location, living standards and economic condition of peoples hailing from same ideologies (Inglehart, 2018; Gourevitch, 1986 \& Boserup, Tan, \& Toulmin, 2013). Labour welfare measures in the form of amenities, environment and other benefits are very important to enhance the standard of living of the employees (Patro, 2017; Venugopal, \& et. al., 2011 \& Bagul, 2014). Fulfillment in the various basic and required amenities helps to employees to attain their satisfaction in both personal and social life (Abramovitz, 2017). Government is establishing the certain statutory guidelines and procedures to the different type of employees based on their nature and level of employment (Harilal, \& et. al., 2006). In general, labour welfare is known as voluntary efforts and benefits given by employer to their employees for the betterment of working conditions (Pigou, 2017 and Jones, 1983).

\section{REVIEW OF LITERATURE}

Srinivasa Rao and Vidyanath (2017) have carried comparative study to examine the effectiveness of statutory welfare measures fulfilment in sugar mills at Krishna District of Andhra Pradesh. The researchers critically evaluated the canteen facility satisfaction among the selected employees of sugar mills. The researchers framed hypothesis test to explore the association between age and statutory welfare measures fulfilment across the different sugar mills selected for the study. The result indicates that age has significant association with welfare measures fulfillment and KCP sugar mills have higher welfare measures fulfillment compared to Delta Sugar Mills and other Sugar mills of Andhra Pradesh.

Neha Rathore and Manish Tanwar (2017) have conducted a comprehensive review of literature to understand the existing body of knowledge with respect to the effect of employee welfare in service industries and the researchers found that still there is gap for offering a wellstructured theoretical model for the better implementation of welfare measures in service industries.

Hemalatha and et.al (2017) have examined the impact of employee welfare facilities on job satisfaction of the workers. The researcher adopted interview method of data collection for the primary survey and applied regression analysis to explore the causal effect of welfare facilities on job satisfaction. The result reveals that welfare facilities have moderate positive effect on job satisfaction of the workers covered for the study. 
Karthi and Poongodi (2016) have tested the employee health and safety welfare measures in RBR garments through case study method of research. The researcher made an in-depth attempt to understand the existing welfare measures prevailing in the Indian textile and garments industry. The researcher adopted survey method to collect responses from 150 employees working RBR garments by adopting random sampling technique. The results indicate that majority of the employees of RBR garments are satisfied with respect to their working conditions, welfare activities and safety measures. Further the researcher also made an attempt to explore the association between the various personal profiles and welfare measures satisfaction and the empirical evidence explicit that age has significant association with welfare measures satisfaction of RBR garment employees.

Ramya and et.al (2016) have conducted an exploratory research study to explore the impact of welfare facilities on employee satisfaction with respect to hotel industries of Mysuru City of Karnataka. The researcher highlighted the various importance and benefits of welfare facilities to enrich the employee satisfaction. The researcher adopted survey method to gather the information from employees through structured questionnaire measured by appropriate dichotomous and multiple-choice questions. The result shows that two dominant factors such as, intramural facilities and extramural facilities in their order of dominance and both these factors have significant influence of employee satisfaction in textile industry.

Syed and Sri Vani Vidyahari (2016) have conducted empirical research study to examine the employee welfare measures at Southern Power Distribution Company of Andhra Pradesh with the primary objective to explore awareness and satisfaction of employee welfare measures of the organisation. The researchers made an attempt to collect information from 101 employees working in the organisation by adopting questionnaire method of survey. The result indicates that, work experiences do not have significant relationship with employee welfare measures and welfare measures have significant positive effect on employee satisfaction.

These studies clear proved that the existing studies have been conducted to explore the welfare facilities, employee satisfaction in textile industries, sugar mills, Government corporations and service industries but, still there is a need for exploring the welfare facilities satisfaction in manufacturing companies to add more valuable insights to existing body of knowledge.

\section{OBJECTIVES OF THE STUDY}

- To study demographic profiles of the employees in manufacturing companies of Chennai city.

- To explore the underlying dominant dimensions of labour welfare measures satisfaction of employees in manufacturing companies.

- To identify the difference in labour welfare measures satisfaction factors with respect to their level of employment, age and educational qualification of employees in manufacturing companies.

\section{RESEARCH METHODOLOGY}

The present study is exploratory in nature and has adopted survey method for its findings. This study is mainly based on the primary data collected from the employees of manufacturing companies of Chennai city through and a well- designed questionnaire. The questionnaire was designed with appropriate nominal and 5 Likert Scale Measurement. However, the valuable efforts are also taken to collect information from all the available published data, especially from websites, newspapers, magazines and journals (National and International).

Sampling Size and Design: Non-random convenient sampling method was adopted for collecting primary data. A total of 300 questionnaires were issued and the respondents were given sufficient time for filling the questionnaire. 250 of the issued questionnaire were received 
back from the respondents. On scrutiny of these 50 of them were found to be incomplete. So, they were rejected and the remaining 200 samples were taken for the study.

Questionnaire Design and Scaling Pattern: A questionnaire with two sections was finalized to collect information from the information sector employees. Section one deals with the various demographic profiles of the respondents. Section two contains with the eleven welfare measures satisfaction variables and it is measured through appropriate 5 point Likert scale. The test the reliability and consistency of the instrument the Cronbach's Alpha reliability coefficient were employed and the value being 0.771 indicates that, the scale is more consistent and highly reliable in nature.

Statistical Software and Tools Selection: The data collected were subjected to analysis using PSPP Version 1.0.1 which is free alternative software for IBM SPSS Statistics. The statistical tools such as, percentage analysis, factor analysis, Independent Samples t test, Analysis of Variance (ANOVA) and weighted average mean score were used to draw meaningful answers to research objectives.

\section{DEMOGRAPHIC PROFILES OF THE RESPESPONDENTS}

Percentage analysis has been applied to understand the sample characteristics of the respondents such as age, educational qualification; years of experience, monthly family income and nature of employment of the respondents and the results are shown in table 1.

Table 1 Sample Characteristics

\begin{tabular}{lc}
\hline & Percentage $(\boldsymbol{N}=\mathbf{2 0 0})$ \\
\hline Age & \\
Below 25 & 24.5 \\
Between 26-30 & 54.5 \\
Between 30-35 & 7.0 \\
Between 36-40 & 13.0 \\
Above 40 & 1.0 \\
Educational Qualification & \\
Graduates & 18.5 \\
Post Graduates & 13.5 \\
Professionals & 10.5 \\
Others & 28.0 \\
Diploma & 29.5 \\
Years of Experience & \\
Below 1 Year & 0.5 \\
1-3 Years & 10.0 \\
4-6 Years & 17.5 \\
7-8 Years & 17.5 \\
Above 8 Years & 54.5 \\
Monthly Family Income (in Rs.) & \\
Upto Rs.20,000 & \\
Between 20,001 to 30,000 & 21.5 \\
Above Rs. 30,000 & 56.0 \\
Nature of Employment & 22.5 \\
Semi-Skilled & \\
Highly Skilled & \\
\hline & \\
\hline
\end{tabular}

The table 1 shows clearly that out of 200 respondents, Majority of the respondents are aged between 26 to 30 years $(54.5 \%)$ followed by, Below 25 years (24.5\%), Between 36 to 40 Years 
(13.0\%), Between 30 to 35 years (7\%) and Above 40 years (1.0\%). Maximum number of respondents is diploma holders $(29.5 \%)$, followed by others $(28.0 \%)$, Graduates $(18.5 \%)$, Post Graduates $(13.5 \%)$ and Professionals $(10.5 \%)$. Majority of them are possess above 8 years of experience $(54.5 \%)$, followed by between $4-6$ years $(17.5 \%)$, between $7-8$ years $(17.5 \%)$, between $1-3$ years $(10.0 \%)$ and Below 1 Year $(0.5 \%)$. Majority of the Respondents are earning Rs. 20,001 to Rs.30,000 (56.0\%), followed by, Above Rs. 30,000 (22.5\%) and Up to Rs.20,000 (21.5\%). Majority of the Respondents are Semi-skilled Workers (81.0\%) followed by Highly Skilled Workers (19.0\%).

\section{FACTOR ANALYSIS OF WELFARE MEASURES SATISFACTION (WMS)}

The factor analysis has been applied to understand the underlying dimensions of eleven Welfare Measures Satisfaction (WMS) Variables and reduce them into a limited number of manageable and independent factors. The Principal Component Analysis of Extraction Method and Rotation Method of Varimax with Kaiser Normalisation have been used in the factor analysis and the results are shown in the tables 2.

Table 2 Factor Loadings of Welfare Measures Satisfaction Variables

\begin{tabular}{|c|c|c|c|c|c|}
\hline $\begin{array}{l}\text { Factor } \\
\text { Names }\end{array}$ & Welfare Measures Satisfaction (WMS) & Mean (SD) & $\begin{array}{l}\text { Commun } \\
\text { alities }\end{array}$ & $\begin{array}{c}\text { Factor } \\
\text { Loadings }\end{array}$ & $\begin{array}{c}\text { Variance } \\
\text { (Eigen value) }\end{array}$ \\
\hline \multirow{5}{*}{$\begin{array}{c}\text { Factor 1 } \\
\text { Amenities } \\
\text { Satisfaction } \\
\text { Factor (ASF) }\end{array}$} & Canteen, Lunch Room & $4.31(0.78)$ & 0.575 & 0.825 & \multirow{5}{*}{$\begin{array}{l}20.581 \\
(2.264)\end{array}$} \\
\hline & Washing Facilities, Washroom facilities & $3.95(0.92)$ & 0.455 & 0.716 & \\
\hline & Crèches, Hygienic Facilities for Women & $4.06(0.71)$ & 0.692 & 0.641 & \\
\hline & Housing Facilities, Transport Facility & $4.27(0.67)$ & 0.434 & 0.536 & \\
\hline & First Aid Box, Ambulance room & $3.90(0.79)$ & 0.580 & 0.471 & \\
\hline \multirow{3}{*}{$\begin{array}{c}\text { Factor } 2 \\
\text { Environment } \\
\text { Satisfaction } \\
\text { Factor (ESF) }\end{array}$} & $\begin{array}{l}\text { Seating arrangements, Working } \\
\text { Environment }\end{array}$ & $4.23(0.66)$ & 0.668 & 0.753 & \multirow{3}{*}{$\begin{array}{r}17.912 \\
(1.970)\end{array}$} \\
\hline & Shelter Room & $4.20(0.71)$ & 0.490 & 0.703 & \\
\hline & Ventilation, Lighting Facilities & $4.22(0.64)$ & 0.571 & 0.595 & \\
\hline \multirow{3}{*}{$\begin{array}{c}\text { Factor } 3 \\
\text { Monetary } \\
\text { Satisfaction } \\
\text { Factor } \\
\text { (MSF) }\end{array}$} & Loan and Financial Grants, Incentives & $4.10(0.70)$ & 0.565 & 0.755 & \multirow{3}{*}{$\begin{array}{r}16.498 \\
(1.815)\end{array}$} \\
\hline & Bank and ATM facility & $4.18(0.86)$ & 0.621 & 0.750 & \\
\hline & Safety Measures & $4.33(0.67)$ & 0.499 & 0.559 & \\
\hline
\end{tabular}

\footnotetext{
KMO and Bartlett's Test

Kaiser-Meyer-Olkin Measure of Sampling Adequacy $=0.695$

Bartlett's Test Approx. Chi-Square $=597.379$

Df $=55 ;$ P- Value $=<0.001$

Extraction Method: Principal Component Analysis
}

Tables 2 shows that the range of communalities of the eleven Welfare Measures Satisfaction variables is from 0.434 to 0.692 with KMO measure of Sampling Adequacy Value of 0.695 and Chi-Square value of 597.379 at d.f of 55 with P-Value of 0.000 in Barlett's Test of Sphericity, the factor Analysis is applicable for factorization of Welfare Measures Satisfaction variables.

Three factors have been extracted and they explain $54.992 \%$ of the variance in the fifteen Welfare Measures Satisfaction variables. The most dominant factor is Factor 1 with the explained variance of $20.581 \%$ and it has five Welfare Measures Satisfaction variables of Canteen, Lunch Room, Washing Facilities, Washroom facilities, Crèches, Hygienic Facilities for Women, Housing Facilities, Transport Facility and First Aid Box, Ambulance room. It has been labelled as Amenities Satisfaction Factor (ASF). 
The second most dominant factor is factor 2 with explained variance of $17.912 \%$ and it has three variables of seating arrangements, Working Environment, Shelter Room and Ventilation, Lighting Facilities. It has been labelled as Environment Satisfaction Factor (ESF).

The third most dominant factor is factor 3 with explained variance of $16.498 \%$ and it has three variables of Loan and Financial Grants, Incentives, Bank and ATM facility and Safety Measures. It has been as Monetary Satisfaction Factor (MSF).

Thus all the eleven Welfare Measures Satisfaction variables have been reduced to three independent factors and the most dominant factor is Amenities Satisfaction Factor (ASF) followed by Environment Satisfaction Factor (ESF) and Monetary Satisfaction Factor (MSF) in their order of dominance.

Table 3 Significance of Difference between Level of Employment and Welfare Measures Satisfaction Factors (ESF)

\begin{tabular}{lcccc}
\hline \multicolumn{1}{c}{ Description } & \multicolumn{2}{c}{ Level of Employment } & & \\
& $\begin{array}{c}\text { Semi-Skilled } \\
\mathbf{( N = 1 6 2 )} \\
\text { Mean (SD) }\end{array}$ & $\begin{array}{c}\text { Highly Skilled } \\
\mathbf{( N = 3 8 )} \\
\text { Mean (SD) }\end{array}$ & $\begin{array}{c}\text { t-Value } \\
\mathbf{( D f}=\mathbf{1 9 8})\end{array}$ & P-Value \\
\hline Amenities Satisfaction Factor (ASF) & $20.97(2.18)$ & $20.18(2.80)$ & 1.943 & 0.004 \\
Environment Satisfaction Factor (ESF) & $12.67(1.70)$ & $12.16(1.99)$ & 1.68 & 0.29 \\
Monetary Satisfaction Factor(MSF) & $12.34(1.64)$ & $12.08(2.17)$ & 0.869 & 0.257 \\
\hline
\end{tabular}

Table 3 shows that, Level of Employment have significant difference in the Amenities Satisfaction Factor (ASF) of Welfare Measures Satisfaction Factors (WMSF). Other Welfare Measures Satisfaction Factors such as, Environment Satisfaction Factor (ESF), Monetary Satisfaction Factor (MSF) does not have significant difference with respect to Level of Employment. Semi-Skilled Employees have higher welfare measures satisfaction in Amenities Satisfaction compared to Highly-Skilled employees.

Table 4 Significance of Difference between Age and Welfare Measures Satisfaction Factors (WMSF)

\begin{tabular}{|c|c|c|c|c|c|c|c|}
\hline \multirow[b]{2}{*}{ Description } & \multicolumn{5}{|c|}{ Age (In Years) } & \multirow[b]{2}{*}{$\begin{array}{c}\text { F-Value } \\
(\mathrm{Df}=195)\end{array}$} & \multirow[b]{2}{*}{ P-Value } \\
\hline & $\begin{array}{c}\text { Below } \\
25 \\
(\mathrm{~N}=49) \\
\text { Mean } \\
\text { (SD) }\end{array}$ & 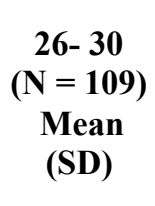 & $\begin{array}{l}30-35 \\
(\mathrm{~N}=14) \\
\text { Mean } \\
(\mathrm{SD})\end{array}$ & $\begin{array}{c}36-40 \\
(\mathrm{~N}=26) \\
\text { Mean } \\
(\mathrm{SD})\end{array}$ & $\begin{array}{c}\text { Above } 40 \\
(\mathbf{N}=2) \\
\text { Mean } \\
\text { (SD) }\end{array}$ & & \\
\hline $\begin{array}{c}\text { Amenities } \\
\text { Satisfaction Factor } \\
\text { (ASF) }\end{array}$ & $\begin{array}{l}21.31 \\
(2.30)\end{array}$ & $\begin{array}{l}20.87 \\
(2.14)\end{array}$ & $\begin{array}{l}20.15 \\
(2.12)\end{array}$ & $\begin{array}{l}20.44 \\
(2.77)\end{array}$ & $\begin{array}{l}17.50 \\
(0.71)\end{array}$ & 2.267 & 0.063 \\
\hline $\begin{array}{c}\text { Environment } \\
\text { Satisfaction Factor } \\
\text { (ESF) }\end{array}$ & $\begin{array}{l}12.51 \\
(1.65)\end{array}$ & $\begin{array}{l}12.88 \\
(1.59)\end{array}$ & $\begin{array}{l}12.00 \\
(2.39)\end{array}$ & $\begin{array}{l}11.83 \\
(2.01)\end{array}$ & $\begin{array}{l}13.00 \\
(1.41)\end{array}$ & 3.231 & $0.013 *$ \\
\hline $\begin{array}{l}\text { Monetary } \\
\text { Satisfaction Factor } \\
\text { (MSF) }\end{array}$ & $\begin{array}{l}12.42 \\
(1.58)\end{array}$ & $\begin{array}{l}12.30 \\
(1.69)\end{array}$ & $\begin{array}{l}12.36 \\
(1.22)\end{array}$ & $\begin{array}{l}12.11 \\
(2.29)\end{array}$ & $\begin{array}{l}12.00 \\
(1.41)\end{array}$ & 0.198 & 0.939 \\
\hline
\end{tabular}

Table 4 shows that, Age have significant difference in the Environment Satisfaction Factor (ESF) of Welfare Measures Satisfaction Factors (ESF). Other Welfare Measures Satisfaction Factors such as, Amenities Satisfaction Factor (ASF) and Monetary Satisfaction Factor (MSF) 
do not have significant difference with respect to their age group. In that Environment Satisfaction Factor (ESF) age group of above 40 years have higher Welfare Measures Satisfaction (ES).

Table 5 Significance of Difference between Educational Qualification and Welfare Measures Satisfaction Factors (WMSF)

\section{Educational Qualification}

\begin{tabular}{|c|c|c|c|c|c|c|c|}
\hline Description & $\begin{array}{c}\text { Graduates } \\
(\mathbf{N}=\mathbf{3 7}) \\
\text { Mean (SD) }\end{array}$ & $\begin{array}{c}\text { Post } \\
\text { Graduates } \\
(\mathbf{N}=27) \\
\text { Mean (SD) }\end{array}$ & $\begin{array}{c}\text { Professional } \\
\mathbf{S} \\
(\mathbf{N}=\mathbf{2 1}) \\
\text { Mean (SD) }\end{array}$ & $\begin{array}{c}\text { Others } \\
(\mathrm{N}=56) \\
\text { Mean } \\
\text { (SD) }\end{array}$ & $\begin{array}{c}\text { Diplom } \\
\text { a } \\
\left(\begin{array}{c}\mathbf{N}=59) \\
\text { Mean } \\
\text { (SD) }\end{array}\right.\end{array}$ & $\begin{array}{c}\text { F-Value } \\
(\mathrm{Df}=195)\end{array}$ & P-Value \\
\hline $\begin{array}{c}\text { Amenities } \\
\text { Satisfaction } \\
\text { Factor (ASF) }\end{array}$ & $\begin{array}{l}21.36 \\
(2.38)\end{array}$ & $\begin{array}{l}21.58 \\
(1.86)\end{array}$ & $\begin{array}{l}20.00 \\
(2.45)\end{array}$ & $\begin{array}{l}20.51 \\
(2.03)\end{array}$ & $\begin{array}{l}20.93 \\
(2.48)\end{array}$ & 2.856 & 0.024 \\
\hline $\begin{array}{l}\text { Environment } \\
\text { Satisfaction } \\
\text { Factor (ESF) }\end{array}$ & $\begin{array}{l}12.19 \\
(1.81)\end{array}$ & $\begin{array}{l}13.38 \\
(1.26)\end{array}$ & $\begin{array}{l}12.68 \\
(1.76)\end{array}$ & $\begin{array}{l}12.63 \\
(1.67)\end{array}$ & $\begin{array}{l}12.42 \\
(1.90)\end{array}$ & 2.412 & 0.05 \\
\hline $\begin{array}{c}\text { Monetary } \\
\text { Satisfaction } \\
\text { Factor (MSF) }\end{array}$ & $\begin{array}{l}12.31 \\
(1.67)\end{array}$ & $\begin{array}{l}12.34 \\
(1.84)\end{array}$ & $\begin{array}{l}12.26 \\
(1.59)\end{array}$ & $\begin{array}{l}12.37 \\
(1.91)\end{array}$ & $\begin{array}{l}12.24 \\
(1.64)\end{array}$ & 0.055 & 0.994 \\
\hline
\end{tabular}

Table 5 reveals that, Educational Qualification have significant difference in the Amenities Satisfaction Factor (ASF) and Environment Satisfaction Factor (ESF) of Employee Satisfaction Factors (WMSF) except Monetary Satisfaction Factor (MSF). Amenities Satisfaction Factor (ASF) and Environment Satisfaction Factor (ESF) post graduates have higher employee satisfaction compared to other educational qualification of groups.

Table 6 Weighted Average Mean Ranking of Importance of Fulfillment of Measures to Enhance Employee Satisfaction

\begin{tabular}{cccc}
\hline $\begin{array}{c}\text { Importance of facilities for } \\
\text { Satisfaction }\end{array}$ & Mean & Standard & Rank \\
\hline Health Measures & 1.92 & 0.765 & 2 \\
Safety Measures & 1.83 & 0.732 & 3 \\
Welfare Measures & 2.42 & 0.911 & 1 \\
\hline
\end{tabular}

Table 6 shows that, Employees are giving importance to welfare measures (2.42), health measures (1.92), and safety measures (1.83) in order to enhance the Welfare Measures Satisfaction.

\section{MAJOR FINDINGS OF THE STUDY}

- Majority of the respondents are aged between 26 to 30 years followed by, Below 25 years, Between 36 to 40 Years, Between 30 to 35 years and Above 40 years. Maximum number of respondents is diploma holders, followed by others, Graduates, Post Graduates and Professionals. Majority of the employees possess above 8 years of experience, followed by between 4-6 years, between 7-8 years, between 1-3 years and Below 1 Year. Majority of the Respondents are earning Rs. 20,001 to Rs.30,000, followed by, Above Rs. 30,000 and Up to Rs.20,000. Majority of the Respondents are Semi-skilled Workers followed by Highly Skilled Workers. 
- Welfare Measures Satisfaction variables have been reduced to three independent factors and the most dominant factor is Amenities Satisfaction Factor (ASF) followed by Environment Satisfaction Factor (ESF) and Monetary Satisfaction Factor (MSF) in their order of dominance.

- Semi-Skilled Employees have higher welfare measures satisfaction in Amenities Satisfaction compared to Highly-Skilled employees.

- Environment Satisfaction Factor (ESF) age group of above 40 years have higher Welfare Measures Satisfaction (ES).

- Amenities Satisfaction Factor (ASF) and Environment Satisfaction Factor (ESF) post graduates have higher employee satisfaction compared to other educational qualification of groups.

- Employees are giving importance to welfare measures (2.42), health measures (1.92), and safety measures (1.83) in order to enhance the Welfare Measures Satisfaction.

\section{IMPLICATION AND CONCLUSION}

- Manufacturing Companies are needed to ensure proper amenities, environment and monetary benefits to enrich their satisfaction with respect to their welfare measures fulfillment.

- Employees opine that, Amenities satisfaction is the dominant aspect need to satisfy by their companies followed by environment satisfaction and monetary benefits satisfaction.

- Since, there is a significant difference in the amenities satisfaction factor with respect to semiskilled and highly skilled employee's welfare satisfaction. The companies are suggested to focus different welfare measures fulfillment based on their level of employment to enhance the employee labour welfare measures satisfaction.

- The manufacturing companies are suggested to strictly follow the labour legislation laws with regard to the fulfillment of welfare measures in their companies to enrich the employee satisfaction.

To conclude, this study was conducted to identify the important dimensions of labour welfare measures satisfaction of employees in manufacturing companies of Chennai city of Tamil Nadu. The empirical result indicates that Amenities Satisfaction Factor (ASF), Environment Satisfaction Factor (ESF) and Monetary Satisfaction Factor (MSF) are the dominant dimension of employee satisfaction with respect to their welfare measures fulfillment. Further, Employees are giving importance to welfare measures, health measures and safety measures in their order of importance to enhance the employee satisfaction.

\section{LIMITATIONS OF THE STUDY AND SCOPE OF FUTURE STUDIES}

The researchers restricted its sample size to 200 Due to time and cost constraint and only employees working in select manufacturing companies of Chennai city were covered for this exploratory research study. Since, this study was adopted non-random convenient sampling technique to collect responses from employees of manufacturing companies. So, the limitation associated with non-random convenient sampling technique is also applicable to this study. This study can be further extended to other unexplored sectors in special economic zones may be extended in near future and labour welfare measures fulfillment and its impact on employee performance can be explored in near future. 
Employee Satisfaction on Labour Welfare Measures: An Empirical Examination of Manufacturing Companies

\section{REFERENCES}

[1] Abramovitz, M. (2017). Regulating the lives of women: Social welfare policy from colonial times to the present. Routledge.

[2] Bagul, D. B. (2014). A Study of "Labour Welfare Facilities" at Ahmednagar Forgings Limited, Pune. International Journal of Entrepreneurship \& Business Environment Perspectives, 3(4), 1257.

[3] Boserup, E., Tan, S. F., \& Toulmin, C. (2013). Woman's role in economic development. Routledge.

[4] Briggs, A. (1961). The welfare state in historical perspective. European Journal of Sociology/Archives europeennes de sociologie, 2(2), 221-258.

[5] Gourevitch, P. (1986). Politics in hard times: comparative responses to international economic crises. Cornell University Press.

[6] Harilal, K. N., Kanji, N., Jeyaranjan, J., Eapen, M., \& Swaminathan, P. (2006). Power in global value chains: implications for employment and livelihoods in the cashew nut industry in India. Summary report London, UK: International Institute for Environment and Development (IIED).

[7] Hemalatha. K. Benita. S. Monica. \& Rao. B.N. (2017). A Study on Impact of Employee Welfare facilities on Job Satisfaction. International Journal of Advance Research and Innovative Ideas in Education, 3(5), 822-826.

[8] Inglehart, R. (2018). Culture shift in advanced industrial society. Princeton University Press.

[9] Jones, H. (1983). Employers' welfare schemes and industrial relations in inter-war Britain. Business History, 25(1), 61-75.

[10] Karthi. G. \& Poongodi. T. (2016). A Study on Employee Health and Safety Welfare Measures with Special Reference to RBR Garments, Tirupur. Intercontinental Journal of Human Resource Management, 3(1), 20-26.

[11] Mishra, S., \& Manju, B. (2007). Principles for successful implementation of labour welfare activities. From police theory to functional theory.

[12] Neha Rathore \& Manish Tanwar. (2017). A Comprehensive Literature Review of Effect on Employees Welfare in Service Industries. International Journal of Management and Social Sciences Research. 6(12), 30-32.

[13] Patro, C. S. (2017). Employee Welfare Measures in Public and Private Sectors: A Comparative Analysis. In Public Health and Welfare: Concepts, Methodologies, Tools, and Applications (pp. 1026-1042). IGI Global.

[14] Pigou, A. (2017). The economics of welfare. Routledge.

[15] Ramya. T.J. Bhavani Shree Arepalli \& Lakshmi. P. (2016). A Study on Employee Welfare Facilities and Its Impact on Employee Satisfaction at Hotel Industry with Special Reference to Mysuru District. International Journal of Engineering Science and Computing, 6(12), 3680-3686.

[16] Rao, M. S., \& Vidyanath, G. (2018). A Comparative Study of Effectiveness of Statutory Employee Welfare Measures-With Special Reference to Canteen Facility in Sugar Mills in Krishna District of Andhra Pradesh. International Journal of Emerging Research in Management and Technology, 6(11), 156-162.

[17] Rhodes, M. (1998). Globalization, labour markets and welfare states: a future of 'competitive corporatism'?. In The future of European welfare (pp. 178-203). Palgrave Macmillan, London. 
[18] Salamon, L. M. (1987). Of market failure, voluntary failure, and third-party government: Toward a theory of government-nonprofit relations in the modern welfare state. Journal of voluntary action research, 16(1-2), 29-49.

[19] Syed. S.M \& Sri Vani Vidyadhari. (2016). A Study on Employee Welfare Measures At Southern Power Distribution Company Limited of Andhra Pradash. EPRA International Journal of Economic and Business Review, 4(12), 148-153.

[20] Tirole, J. (1994). The internal organization of government. Oxford Economic Papers, 1-29.

[21] Venugopal, D., Bhaskar, T., Principal, V., \& Usha, P. (2011). Employee welfare activities with respective measures in industrial sector-A study on industrial cluster at Chittor District. Chief Patron. 